\title{
Action of Cholecystokinin and Cholinergic Agents on Membrane-Bound Calcium in Dispersed Pancreatic Acinar Cells
}

\author{
Harold T. Shelby, Leroy P. Gross, Peter Lichty, and Jerry D. Gardner \\ From the Section on Gastroenterology, Digestive Diseases Branch, National Institute of Arthritis, \\ Metabolism, and Digestive Diseases, National Institutes of Health, Bethesda, Maryland 20014
}

\begin{abstract}
A B S T R A C T In dispersed acinar cells prepared from guinea pig pancreas, cellular uptake of ${ }^{45} \mathrm{Ca}$ was moderately rapid and reached a steady state by $60 \mathrm{~min}$. At the steady state, $69 \%$ of total cellular ${ }^{45} \mathrm{Ca}$ was membrane-bound. In acinar cells preloaded with ${ }^{45} \mathrm{Ca}$ and then incubated with $\mathrm{COOH}$-terminal octapeptide of cholecystokinin (CCK-OP) or carbamylcholine, total cellular ${ }^{45} \mathrm{Ca}$ decreased by approximately $40 \%$ within 5-10 min and then steadily increased to control values by $60 \mathrm{~min}$. Under identical conditions, membranebound ${ }^{45} \mathrm{Ca}$ decreased by $40 \%$ within $5-10 \mathrm{~min}$ and remained constant for the duration of the incubation. Free cellular ${ }^{45} \mathrm{Ca}$ did not change during the initial 30 min but then increased steadily to values three times those in control cells by $60 \mathrm{~min}$. In cells preloaded with ${ }^{45} \mathrm{Ca}$ and then incubated with EDTA, the loss of total cellular radioactivity stimulated by CCK-OP could be accounted for by loss of membrane-bound ${ }^{45} \mathrm{Ca}$. CCK-OP failed to alter total cellular uptake of ${ }^{45} \mathrm{Ca}$ when both tracer and peptide were added at the beginning of the incubation. Under identical conditions, membrane-bound ${ }^{45} \mathrm{Ca}$ was not altered by CCK-OP during the first $30 \mathrm{~min}$ of incubation but was significantly below control values after this time. The effect of CCK-OP on free cellular ${ }^{45} \mathrm{Ca}$ was the same as in cells preloaded with the tracer. These results suggest that CCK-OP causes release of ${ }^{45} \mathrm{Ca}$ from a membrane-bound compartment that equilibrates slowly with extracellular fluid and that the change in free cellular ${ }^{45} \mathrm{Ca}$ is a secondary effect.
\end{abstract}

\section{INTRODUCTION}

Cholecystokinin and muscarinic cholinergic agents cause loss of exchangeable cellular calcium from

Received for publication 8 March 1976 and in revised form 12 July 1976. whole pancreas (1), pancreatic fragments (2-4), and dispersed pancreatic acinar cells $(5,6)$. In previous studies $(5,6)$, we have shown that the loss of ${ }^{45} \mathrm{Ca}$ from dispersed pancreatic acinar cells caused by cholecystokinin or carbamylcholine results from the secretagogue producing a four- to fivefold increase in ${ }^{45} \mathrm{Ca}$ outflux. Coincident with this stimulation of ${ }^{45} \mathrm{Ca}$ outflux, there is a 10 -fold increase in cellular cyclic GMP $(6)$ but no change in cellular cyclic $\operatorname{AMP}(7,8)$. The ability of cholecystokinin and cholinergic agents to stimulate the loss of exchangeable cell calcium has led some $(1,3,4,9)$ to propose that secretagogues effect release of intracellular stored calcium and increase free cytoplasmic calcium. To date, however, no data are available to support or refute this hypothesis.

In the present studies we have developed a method to measure the membrane-bound portion of exchangeable cell calcium in pancreatic acinar cells and have used this technique to explore how the functional compartmentalization of exchangeable calcium is altered by cholecystokinin and cholinergic agents. We have found that in acinar cells the loss of ${ }^{45} \mathrm{Ca}$ caused by cholecystokinin or carbamylcholine results from release of membrane-bound ${ }^{45} \mathrm{Ca}$, with no detectable change in free cellular ${ }^{45} \mathrm{Ca}$.

\section{METHODS}

Male Hartley strain albino guinea pigs (350-400 g) were obtained from the Small Animals Section, Veterinary Resources Branch, National Institutes of Health, Bethesda, Md. ${ }^{45} \mathrm{Ca}(12.5 \mathrm{mCi} / \mathrm{mg})$ and $\left[{ }^{11} \mathrm{C}\right.$ ]alpha-aminoisobutyric acid (AIB, $\left.{ }^{1} 5.1 \mathrm{mCi} / \mathrm{mmol}\right)$ were purchased from New England Nuclear (Boston, Mass.); ${ }^{42} \mathrm{~K}(2.6 \mathrm{mCi} / \mathrm{mg})$ from ICN Corp., Irvine, Calif.); crude collagenase (Clostridium histolyticum,

\footnotetext{
${ }^{1}$ Abbreviations used in this paper: AIB, alpha-aminoisobutyric acid; CCK-OP, COOH-terminal octapeptide of cholecystokinin.
} 
EC 3.4.4.19), crude bovine-testis hyaluronidase (EC 3.2.1.35), carbamylcholine, and atropine sulfate from Sigma Chemical Co. (St. Louis, Mo.); chromatographically purified soybean trypsin inhibitor from Worthington Biochemical Corp. (Freehold, N. J.); bovine plasma albumin from Miles Laboratory, Inc. (Elkhart, Ind.); and blue starch polymer from Pharmacia Laboratories, Inc. (Piscataway, N. J.). All other reagents were of the highest grade commercially obtainable. The following synthetic analogs and fragments of porcine cholecystokinin were generously provided by Dr. Miguel Ondetti, Squibb Institute for Medical Research: COOHterminal octapeptide (SQ 19,844), heptapeptide (SQ 20,204), hexapeptide (SQ 20,294), and desulfated octapeptide (SQ 19,265).

Animals fasted overnight were killed by a blow to the head. The pancreas was dissected free from fat and mesentery and dispersed acinar cells were prepared by the technique of Amsterdam and Jamieson (10-12), with the minor modifications published previously (5-7). After the tissue was digested, cells were dispersed by repeated passage through a Pasteur pipet and the resulting suspension was filtered through nylon mesh screen (114T Nytex, Northern Fibre Products Co., Holland, Mich.) to remove undigested tissue fragments. Unless otherwise specified, dispersed cells (5-20 $\times 10^{6}$ cells $/ \mathrm{ml}$ ) were suspended in standard buffer composed of Krebs-Ringer bicarbonate ( $\mathrm{pH} 7.4$ ), containing $\mathrm{L}$-amino acid supplement (13), $0.1 \mathrm{mg} / \mathrm{ml}$ soybean trypsin inhibitor, $14 \mathrm{mM}$ glucose, $1 \%$ (wt/vol) albumin, and $0.5 \mathrm{mM}$ calcium, and gassed with $95 \% \mathrm{O}_{2}$ and $5 \% \mathrm{CO}_{2}$. Cell concentration was determined by counting a properly diluted suspension in a standard hemocytometer.

To measure total cellular calcium content, acinar cells were incubated at $37^{\circ} \mathrm{C}$ for $60 \mathrm{~min}$ in the standard buffer. At the end of the incubation, the cells were washed three times with at least $60 \mathrm{vol}$ of iced $\left(4^{\circ} \mathrm{C}\right)$ solution composed of $150 \mathrm{mM}$ sodium chloride and $10 \mathrm{mM}$ Tris chloride $(\mathrm{pH} 7.4)$ by alternate centrifugation at $1,000 \mathrm{~g}$ for $5 \mathrm{~min}$ and resuspension. Cells were then treated with $10 \mathrm{vol}$ of $10 \%$ ( $\mathrm{vol} / \mathrm{vol}$ ) perchloric acid, agitated vigorously, and centrifuged at $10,000 \mathrm{~g}$ for 15 min. The supernatant was removed, diluted with $15 \mathrm{mM}$ lanthanum chloride, and assayed for calcium concentration in a Perkin-Elmer atomic absorption spectrophotometer (PerkinElmer Corp., Norwalk, Conn.). All standards were prepared in $10 \%$ (vol/vol) perchloric acid and diluted with $15 \mathrm{mM}$ lanthanum chloride.

Total uptake of ${ }^{45} \mathrm{Ca}$ by dispersed pancreatic acinar cells was determined by incubating cells at $37^{\circ} \mathrm{C}$ in standard buffer containing $0.5 \mathrm{mM}{ }^{45} \mathrm{Ca}$, gassed with $95 \% \mathrm{O}_{2}, 5 \% \mathrm{CO}_{2}$. At appropriate times, duplicate $100-\mu \mathrm{l}$ samples were taken and cellular ${ }^{45} \mathrm{Ca}$ was determined by the microcentrifugation technique reported previously $(5,6)$. Cellular uptake of ${ }^{45} \mathrm{Ca}$ was also determined by adding triplicate $100-\mu$ l samples to $10 \mathrm{ml}$ of iced wash solution containing $150 \mathrm{mM} \mathrm{NaCl}, 10 \mathrm{mM}$ Tris $\mathrm{Cl}(\mathrm{pH} 7.4)$, and $10 \mathrm{mM}$ EDTA. This mixture was immediately poured over a Millipore filter (RAWP $1.2 \mu \mathrm{m}$, Millipore Corp., Bedford, Mass.). The cells retained on the filter were then washed twice with $10 \mathrm{ml}$ iced wash solution after which the filters were added to liquid scintillation fluid to determine radioactivity. ${ }^{45} \mathrm{Ca}$ trapped between cells or adhering to the microfuge tube or to the filter was determined by measuring ${ }^{45} \mathrm{Ca}$ uptake in cells incubated with $0.5 \mathrm{mM}$ ${ }^{45} \mathrm{Ca}$ plus $5 \mathrm{mM}$ EDTA. All results were corrected for this background value (Table I). Values for total uptake of ${ }^{45} \mathrm{Ca}$ obtained by the filtration technique were not significantly different from those obtained by microcentrifugation (Table I). The filtration technique was used for all of the experiments in this paper because it has advantges over the centrifugation procedure in that the cells could be processed more
TABLE I

Total Uptake of ${ }^{45} \mathrm{Ca}$ by Dispersed Guinea Pig Pancreatic Acinar Cells Determined by Two Different Techniques

\begin{tabular}{|c|c|c|}
\hline \multirow[b]{2}{*}{ Incubation } & \multicolumn{2}{|c|}{ Cellular ${ }^{45} \mathrm{Ca}$} \\
\hline & Filtration & Centrifugation \\
\hline & \multicolumn{2}{|c|}{$\begin{array}{l}\text { fraction of added } \\
\text { radioactivity } \times 10^{5}\end{array}$} \\
\hline (a) Control & $567 \pm 46$ & $700 \pm 111$ \\
\hline (b) EDTA (5 mM) & $51 \pm 6$ & $170 \pm 21$ \\
\hline$a-b$ & 516 & 530 \\
\hline
\end{tabular}

Dispersed pancreatic acinar cells were incubated in standard buffer containing $0.5 \mathrm{mM}{ }^{45} \mathrm{Ca}$ with or without $5 \mathrm{mM}$ EDTA at $37^{\circ} \mathrm{C}$ for $60 \mathrm{~min}$. Triplicate $100-\mu \mathrm{l}$ samples were taken and cellular radioactivity was determined by filtration or by centrifugation as described in Methods. Total cellular uptake of ${ }^{45} \mathrm{Ca}(a-b)$ was calculated as cellular ${ }^{45} \mathrm{Ca}$ in cells incubated without, minus that in cells incubated with, $5 \mathrm{mM}$ EDTA. Results shown are means of three separate experiments.

rapidly (20 s vs. $120 \mathrm{~s}$ with the microcentrifuge), it gave lower values for ${ }^{45} \mathrm{Ca}$ background, and it tended to give more precise values (Table I).

Membrane-bound ${ }^{45} \mathrm{Ca}$ in dispersed pancreatic acinar cells was determined by incubating cells exactly as for determination of total uptake of ${ }^{45} \mathrm{Ca}$. At appropriate times, triplicate $100-\mu l$ samples were added to $10 \mathrm{ml}$ of iced hypotonic lysing solution composed of $10 \mathrm{mM}$ EDTA (pH 7.4). ${ }^{2}$ The mixture was immediately poured over a Millipore filter (RAWP 1.2 $\mu \mathrm{m})$ and the membranes retained on the filter were washed twice with $10 \mathrm{ml}$ of iced lysing solution. The filters were then added to liquid scintillation fluid to determine radioactivity. ${ }^{45} \mathrm{Ca}$ trapped between membranes or adhering to the filter was determined by measuring bound ${ }^{45} \mathrm{Ca}$ in cells incubated with $0.5 \mathrm{mM}{ }^{45} \mathrm{Ca}$ plus $5 \mathrm{mM}$ EDTA. All results were corrected for this background value. Free ${ }^{45} \mathrm{Ca}$ was calculated as the difference between total cellular ${ }^{45} \mathrm{Ca}$ and membranebound ${ }^{45} \mathrm{Ca}$.

The amount of ${ }^{45} \mathrm{Ca}$ taken up by pancreatic acinar cells as well as the amount membrane-bound was calculated from net cellular radioactivity, the specific activity of ${ }^{45} \mathrm{Ca}$ in the incubation solution, and the cell concentration. Liquid scintillation counting was performed with a Packard model 3320 liquid scintillation counter (Packard Instrument Co. Inc., Downers Grove, Ill.). Liquid scintillation solution was composed of 15 parts toluene (J. T. Baker Chemical Co. Phillipsburg, N. J.), 5 parts Triton X-100 (New England Nuclear Corp.), and 1 part Liquifluor (New England Nuclear Corp.).

To examine the extent to which treating cells with $10 \mathrm{mM}$ EDTA disrupted subcellular organelles, ${ }^{3}$ dispersed pancreatic acinar cells were homogenized in $12 \mathrm{ml}$ of iced $\left(4^{\circ} \mathrm{C}\right) 0.3 \mathrm{M}$ sucrose, pH 5.5, by 20 strokes of a Teflon-glass homogenizer

${ }^{2}$ EDTA was added to chelate unbound ${ }^{45} \mathrm{Ca}$ and prevent its adsorbing to or associating with various cellular constituents after disruption of the cell.

${ }^{3}$ Adherence of native amylase and native DNA to the Millipore filter prevented us from assaying the material retained on the filter for the presence of intact nuclei and zymogen granules. 


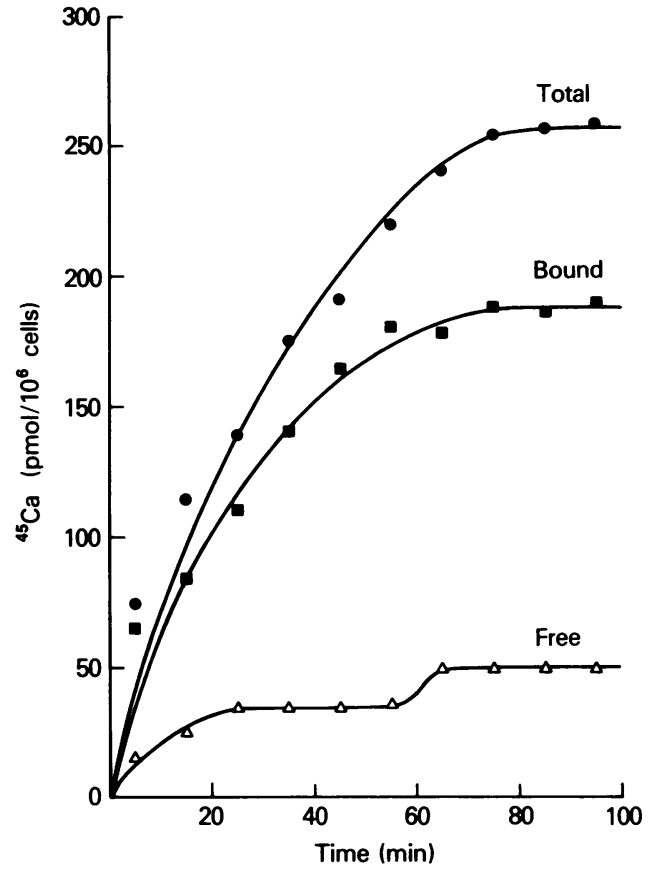

FIgURE 1 Uptake of ${ }^{45} \mathrm{Ca}$ by dispersed guinea pig pancreatic acinar cells. Dispersed cells were preincubated in KrebsRinger bicarbonate ( $\mathrm{pH} 7.4$ ) containing $1 \%$ (wt/vol) albumin and $0.5 \mathrm{mM}$ calcium at $37^{\circ} \mathrm{C}$ for $30 \mathrm{~min}$. At the end of the preincubation, ${ }^{45} \mathrm{Ca}$ (approximately $8 \times 10^{6} \mathrm{cpm} / \mathrm{ml}$ of cell suspension) was added and the cells were incubated at $37^{\circ} \mathrm{C}$. Total, membrane-bound, and free cellular ${ }^{45} \mathrm{Ca}$ were determined at the times indicated. Each point was determined in triplicate and represents the mean from 10 seperate experiments.

driven by a motor at $2,700 \mathrm{rpm}$. An equal volume of cells was added to $12 \mathrm{ml}$ of iced $10 \mathrm{mM}$ EDTA, pH 7.4. Each mixture was centrifuged at $150 \mathrm{~g}$ for $10 \mathrm{~min}$ to sediment nuclei, plasma membranes, and intact cells (14). The supernatant was removed and centrifuged at $1,000 \mathrm{~g}$ for $10 \mathrm{~min}$ to sediment zymogen granules (14). The supernatant was again removed and centrifuged at $9,000 \mathrm{~g}$ for $10 \mathrm{~min}$ to sediment mitochondria (14). Each pellet, as well as an aliquot of the original mixtures, was diluted appropriately in $2 \%$ (wt/vol) sodium dodecyl sulfate and assayed for DNA by the method of Kissane and Robins (15), for amylase with blue starch polymer by method of Ceska et al. $(16,17)$, and for succinic dehydrogenase by the method of Pennington (18).

Concentrations of DNA, amylase, and succinic dehydrogenase were the same in the two mixtures. In four separate experiments for the cells homogenized in sucrose, $94 \pm 9 \%$ (mean \pm 1 SD) of the DNA sedimented at $150 \mathrm{~g}, 68 \pm 7 \%$ of the amylase activity sedimented at $1,000 \mathrm{~g}$, and $85 \pm 6 \%$ of the succinic dehydrogenase activity sedimented at $9,000 \mathrm{~g}$. The corresponding values for cells treated with $10 \mathrm{mM}$ EDTA (pH 7.4) were DNA, $7 \pm 3 \%$; amylase $1 \pm 2 \%$; succinic dehydrogenase $91 \pm 7 \%$. These results indicate that adding iced, $10 \mathrm{mM}$ EDTA (pH 7.4) to pancreatic acinar cells disrupts nuclei and zymogen granules but not the inner mitochondrial membrane matrix (19). Others (20) have found that hypotonic solutions rupture the outer mitochondrial membrane, leaving the inner membrane plus matrix intact.

\section{RESULTS}

As reported previously (5), cellular uptake of ${ }^{45} \mathrm{Ca}$ by dispersed pancreatic acinar cells was moderately rapid and appeared to reach a steady state by $60 \mathrm{~min}$ (Fig. 1). The time-course for cellular accumulation of membrane-bound ${ }^{45} \mathrm{Ca}$ was similar to that for total cellular ${ }^{45} \mathrm{Ca}$, and approximately $70 \%$ of the total cellular ${ }^{45} \mathrm{Ca}$ was membrane-bound. Free cellular ${ }^{45} \mathrm{Ca}$ (calculated as the difference between total and bound ${ }^{45} \mathrm{Ca}$ ) increased during the first $30 \mathrm{~min}$ of incubation, remained constant for the next $25 \mathrm{~min}$, and then increased by approximately $50 \%$ to a second plateau by $60 \mathrm{~min}$. After incubation of dispersed pancreatic acinar cells at $37^{\circ} \mathrm{C}$ for $60 \mathrm{~min}$ in standard buffer containing $0.5 \mathrm{mM}$ calcium, total cellular calcium was $6,582 \pm 873 \mathrm{pmol} / 10^{6}$ cells (mean of five experiments $\pm 1 \mathrm{SD})$. In these same cells incubated at $37^{\circ} \mathrm{C}$ for $60 \mathrm{~min}$ with $0.5 \mathrm{mM}{ }^{45} \mathrm{Ca}$, total cellular ${ }^{45} \mathrm{Ca}$ was $261 \pm 32 \mathrm{pmol} / 10^{6}$ cells.

Uptake and binding of ${ }^{45} \mathrm{Ca}$ by dispersed pancreatic acinar cells were compared with those of ${ }^{42} \mathrm{~K}$ and $\left[{ }^{14} \mathrm{C}\right] \mathrm{AIB}$, two substances accumulated by most eukaryotic cells (Table II). Of the ${ }^{45} \mathrm{Ca}$ taken up by acinar cells, $69 \%$ was membrane-bound. In contrast, of the ${ }^{42} \mathrm{~K}$ or $\left[{ }^{14} \mathrm{C}\right] \mathrm{AIB}$ taken up by acinar cells, virtually none was membrane-bound.

To investigate the kinetics with which cellular ${ }^{45} \mathrm{Ca}$ is lost, cells were preincubated at $37^{\circ}$ for $60 \mathrm{~min}$ with $0.5 \mathrm{mM}{ }^{45} \mathrm{Ca}$ and then incubated with $5 \mathrm{mM}$ EDTA. EDTA chelates extracellular ${ }^{45} \mathrm{Ca}$ and by so doing abolishes ${ }^{45} \mathrm{Ca}$ influx (i.e. the unidirectional movement of ${ }^{45} \mathrm{Ca}$ from the incubation medium into the cell); therefore, the decrease in cellular ${ }^{45} \mathrm{Ca}$ reflects outflux of ${ }^{45} \mathrm{Ca}$. After EDTA was added, total cellular ${ }^{45} \mathrm{Ca}$ decreased by $60 \%$ during the 95 -min incubation

TABLE II

Distribution of ${ }^{45} \mathrm{Ca},{ }^{42} \mathrm{~K}$ and $\left[{ }^{14} \mathrm{C}\right] \mathrm{AIB}$ in Dispersed Guinea Pig Pancreatic Acinar Cells

\begin{tabular}{|c|c|c|}
\hline \multirow[b]{2}{*}{ Incubation } & \multicolumn{2}{|c|}{ Total cellular uptake } \\
\hline & Bound & Free \\
\hline & \multicolumn{2}{|c|}{$c p m$} \\
\hline${ }^{45} \mathrm{Ca}$ & $69.0 \pm 7.0$ & $31.0 \pm 5.2$ \\
\hline${ }^{42} \mathrm{~K}$ & $3.0 \pm 2.0$ & $97.0 \pm 7.5$ \\
\hline$\left[{ }^{14} \mathrm{C}\right] \mathrm{AIB}$ & $3.6 \pm 2.4$ & $96.4 \pm 8.1$ \\
\hline
\end{tabular}

Dispersed pancreatic acinar cells were preincubated in standard buffer at $37^{\circ}$ for $30 \mathrm{~min} .{ }^{45} \mathrm{Ca}$ (final concentration, $0.5 \mathrm{mM}),{ }^{42} \mathrm{~K}(5.5 \mathrm{mM})$, or $\left[{ }^{14} \mathrm{C}\right] \mathrm{AIB}(0.3 \mathrm{mM})$ was added and the cells were incubated at $37^{\circ}$ for $60 \mathrm{~min}$. Total uptake, membrane-bound, and free radioactivity were determined as given in Methods. Results given are means of four separate experiments $\pm 1 \mathrm{SD}$. 

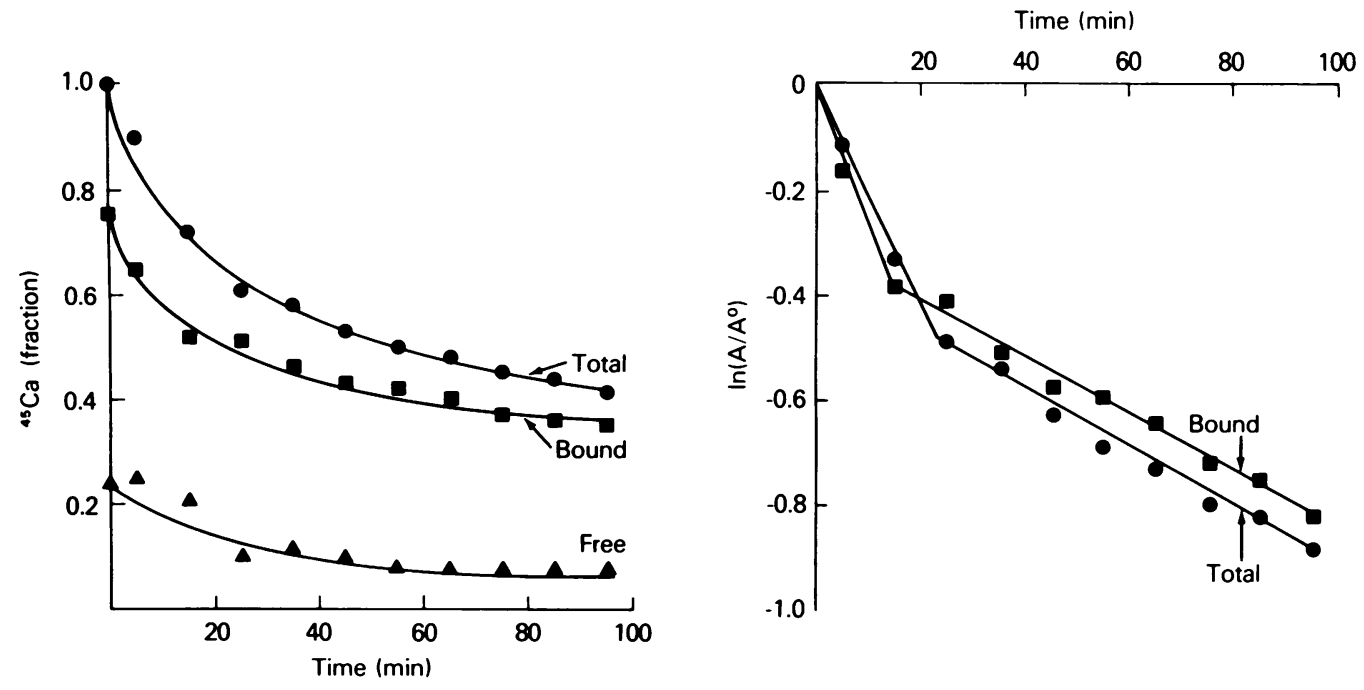

Figure 2 Loss of ${ }^{45} \mathrm{Ca}$ from dispersed guinea pig pancreatic acinar cells. Dispersed cells were preincubated in Krebs-Ringer bicarbonate (pH 7.4) containing $1 \%(\mathrm{wt} / \mathrm{vol})$ albumin and $0.5 \mathrm{mM}{ }^{45} \mathrm{Ca}$ for $60 \mathrm{~min}$ at $37^{\circ} \mathrm{C}$. $5 \mathrm{mM}$ EDTA was added and the incubation continued for $95 \mathrm{~min}$ at $37^{\circ} \mathrm{C}$. In the left panel, total, membrane-bound, and free cellular ${ }^{45} \mathrm{Ca}$ were determined at the times indicated. Each point was determined in triplicate and represents the mean from eight separate experiments. The right panel is a semilogarithmic plot of the data in the left panel. Total and membrane-bound ${ }^{45} \mathrm{Ca}$ are plotted as the natural logarithm of the fraction of the amount originally present versus time.

(Fig. 2). A plot of the natural logarithm of total cellular ${ }^{45} \mathrm{Ca}$ versus time reflected at least two components to the process by which ${ }^{45} \mathrm{Ca}$ was lost from pancreatic acinar cells (Fig. 2). There was an initial, relatively rapid loss of $40 \%$ of cellular radioactivity during the first $25 \mathrm{~min}$, followed by a second, slower loss of $20 \%$ of cellular radioactivity during the subsequent $70 \mathrm{~min}$. At the beginning of the incubation approximately $75 \%$ of cellular ${ }^{45} \mathrm{Ca}$ was membrane-bound (Fig. 2). After EDTA was added, the rates of loss of membranebound ${ }^{45} \mathrm{Ca}$ paralleled those for total cellular ${ }^{45} \mathrm{Ca}$, i.e. approximately $30 \%$ of bound ${ }^{45} \mathrm{Ca}$ was lost during the initial $15 \mathrm{~min}$ and an additional $25 \%$ was lost during the subsequent $80 \mathrm{~min}$ (Fig. 2). The fractional loss of free ${ }^{45} \mathrm{Ca}$ was similar to that of membranebound ${ }^{45} \mathrm{Ca}$.

In agreement with previous findings $(5,6)$, after CCK-OP was added to cells preloaded with ${ }^{45} \mathrm{Ca}$ for $60 \mathrm{~min}$, total cellular ${ }^{45} \mathrm{Ca}$ decreased rapidly, reached a minimum after 5-10 $\mathrm{min}$, and then steadily increased to control values during the subsequent $50 \mathrm{~min}$ (Fig. 3). Total cellular nonradioactive calcium did not change (results not shown). Under identical conditions, after CCK-OP was added, membranebound ${ }^{45} \mathrm{Ca}$ decreased rapidly, reached a minimum after $5 \mathrm{~min}$, and remained significantly below control values for the duration of the 95-min incubation (Fig. 3). After CCK-OP was added, free ${ }^{45} \mathrm{Ca}$ did not change during the initial $30 \mathrm{~min}$ of incubation but then steadily increased to values three times greater than control by $60 \mathrm{~min}$ (Fig. 3). Carbamylcholine ( 0.5 $\mathrm{mM}$ ) produced changes in membrane-bound and free ${ }^{45} \mathrm{Ca}$ identical to those produced by CCK-OP (results not shown.

In contrast to its ability to decrease transiently total cellular ${ }^{45} \mathrm{Ca}$ in cells preloaded with the tracer, CCK-OP did not alter total cellular uptake of ${ }^{45} \mathrm{Ca}$ in cells preincubated for $60 \mathrm{~min}$ with $0.5 \mathrm{mM}$ calcium and then incubated with ${ }^{45} \mathrm{Ca}$ plus CCK-OP (Fig. 4). Results similar to those given in Fig. 4 were obtained when the peptide was added $15,30,45$, or $60 \mathrm{~min}$ before the tracer. Under identical conditions, membrane-bound ${ }^{45} \mathrm{Ca}$ in cells incubated with CCK-OP was the same as in control cells during the first 30 min of incubation, but was significantly below control values for the remainder of the incubation (Fig. 4). As we observed in cells preloaded with the tracer, free cellular ${ }^{45} \mathrm{Ca}$ did not change during the initial 30 min of incubation with CCK-OP but then increased to values two to three times greater than control by $60 \mathrm{~min}$ (Fig. 4).

As reported previously $(5,6)$, in cells preincubated for $60 \mathrm{~min}$ at $37^{\circ}$ with $0.5 \mathrm{mM}{ }^{45} \mathrm{Ca}$ and then incubated with $5 \mathrm{mM}$ EDTA, adding CCK-OP significantly increased the rate of loss of total cellular ${ }^{45} \mathrm{Ca}$ (Fig. 5). A plot of the natural logarithm of total cellular ${ }^{45} \mathrm{Ca}$ versus time reflected at least three components to the loss of total cellular ${ }^{45} \mathrm{Ca}$ from acinar 

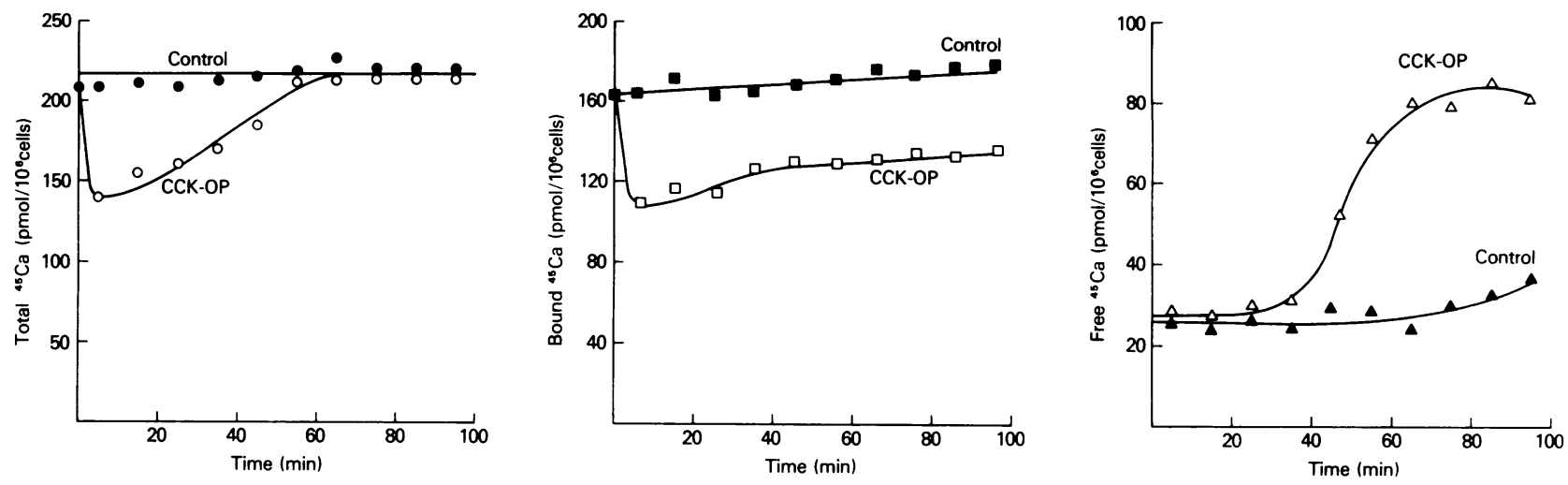

FIGURE 3 Effect of CCK-OP on cellular ${ }^{45} \mathrm{Ca}$ in dispersed guinea pig pancreatic acinar cells. Dispersed cells were preincubated in Krebs-Ringer bicarbonate (pH 7.4) containing $1 \%\left(\mathrm{wt} / \mathrm{vol}\right.$ ) albumin and $0.5 \mathrm{mM}{ }^{45} \mathrm{Ca}$ for $60 \mathrm{~min}$ at $37^{\circ} \mathrm{C}$. At the end of the preincubation $1 \mu \mathrm{M}$ CCK-OP was added and at the indicated times total cellular ${ }^{45} \mathrm{Ca}$ (left panel), membrane-bound ${ }^{45} \mathrm{Ca}$ (center panel), and free ${ }^{45} \mathrm{Ca}$ (right panel) were determined. Each point was determined in triplicate and represents the mean of 10 separate experiments.

cells incubated with CCK-OP plus EDTA (Fig. 5). There was a rapid loss of $63 \%$ of total cellular ${ }^{45} \mathrm{Ca}$ during the initial $5 \mathrm{~min}$, after which the tracer was lost more slowly for the subsequent $50 \mathrm{~min}$ and then at a still slower rate for the final $40 \mathrm{~min}$ of incubation. Under identical conditions, CCK-OP also significantly increased the rate of loss of membranebound ${ }^{45} \mathrm{Ca}$ (Fig. 6). The kinetics of the loss of membrane-bound ${ }^{45} \mathrm{Ca}$ from cells incubated with CCK-OP plus EDTA (Fig. 6) were similar to those for loss of total cellular ${ }^{45} \mathrm{Ca}$ (Fig. 5), i.e. an initial rapid component lasting $5 \mathrm{~min}$, a second slower com- ponent lasting $50 \mathrm{~min}$, and a third still slower component during the final $40 \mathrm{~min}$ of incubation. Results similar to those illustrated in Figs. 5 and 6 were also obtained with $0.5 \mathrm{mM}$ carbamylcholine (not shown).

Stimulation of the release of membrane-bound ${ }^{45} \mathrm{Ca}$ was a saturable function of the concentration of CCK-OP (Fig. 7). Significant effects could be detected with $0.1 \mathrm{mM}$ CCK-OP and stimulation was maximal at $0.1 \mu \mathrm{M}$. The $\mathrm{COOH}$-terminal heptapeptide of cholecystokinin (CCK-HEPTA) was 10 times less potent than CCK-OP in stimulating release of mem-
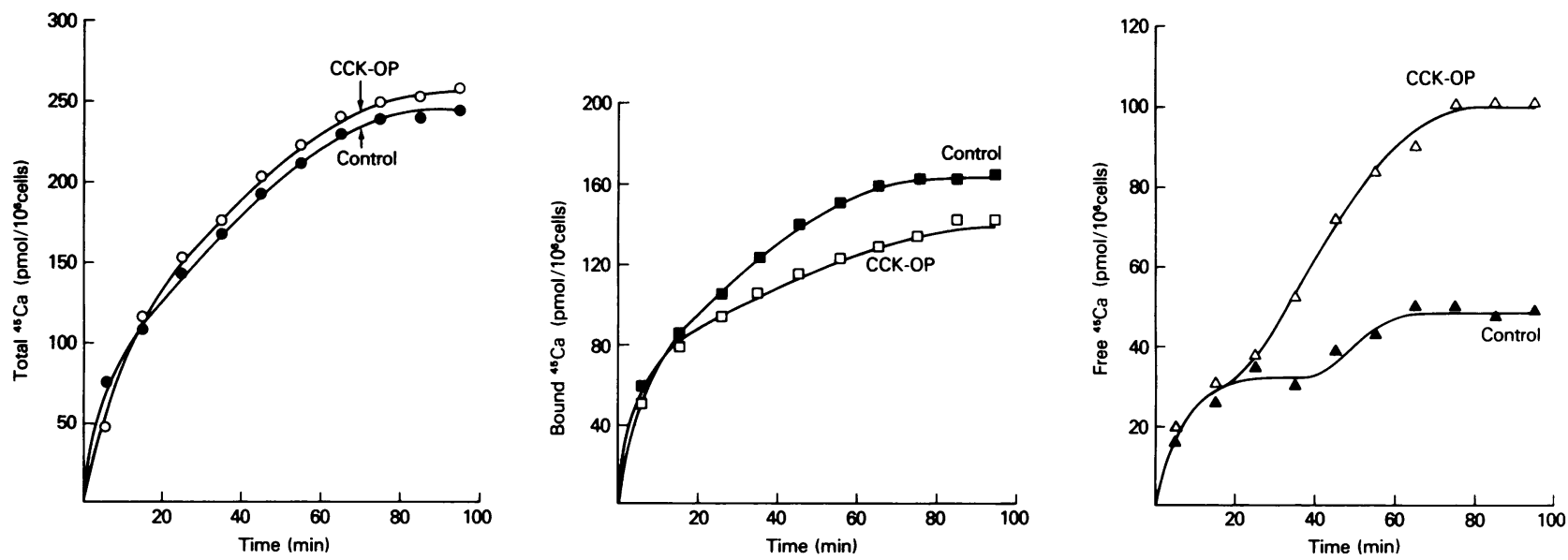

FIGURE 4 Effect of CCK-OP on uptake of ${ }^{45} \mathrm{Ca}$ by dispersed guinea pig pancreatic acinar cells. Dispersed cells were preincubated in Krebs-Ringer bicarbonate ( $\mathrm{pH} 7.4$ ) containing $1 \%$ (wt/vol) albumin and $0.5 \mathrm{mM} \mathrm{Ca}$ for $30 \mathrm{~min}$ at $37^{\circ} \mathrm{C} .{ }^{45} \mathrm{Ca}$ (approximately $8 \times 10^{6} \mathrm{cpm} / \mathrm{ml}$ cell suspension) with or without $1 \mu \mathrm{M}$ CCK-OP was then added and at the indicated times total cellular ${ }^{45} \mathrm{Ca}$ (left panel), membrane-bound ${ }^{45} \mathrm{Ca}$ (center panel), and free ${ }^{45} \mathrm{Ca}$ (right panel) were determined. Each point was determined in triplicate and represents the mean of 10 separate experiments. 

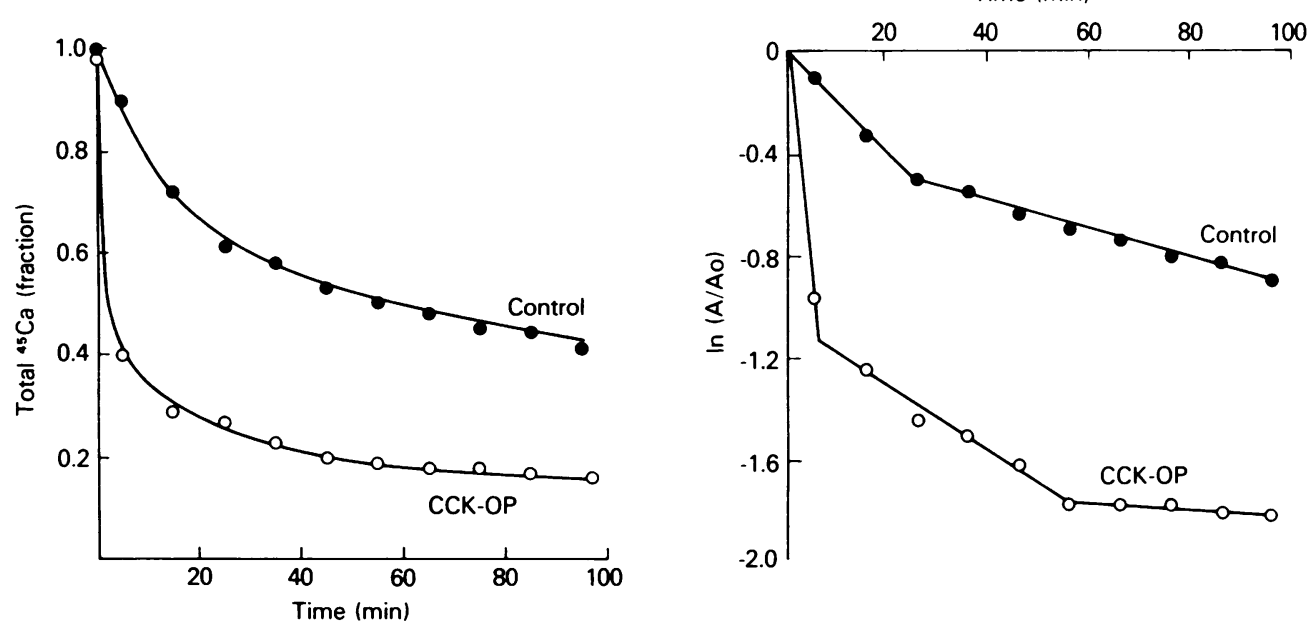

FIGURE 5 Effect of CCK-OP on the loss of total cellular ${ }^{45} \mathrm{Ca}$ from dispersed guinea pig pancreatic acinar cells. Dispersed cells were preincubated in Krebs-Ringer bicarbonate (pH 7.4) containing $1 \%$ (wt/vol) albumin and $0.5 \mathrm{mM}{ }^{45} \mathrm{Ca}$ for $60 \mathrm{~min}$ at $37^{\circ} \mathrm{C}$. $5 \mathrm{mM}$ EDTA with or without $1 \mu \mathrm{M}$ CCK-OP was added and total cellular ${ }^{45} \mathrm{Ca}$ was determined at the times indicated during a 95 -min incubation at $37^{\circ} \mathrm{C}$ (left panel). Each point was determined in triplicate and represents the mean of five separate experiments. In the right panel, the natural logarithm of the fraction of the amount of total cellular ${ }^{45} \mathrm{Ca}$ originally present is plotted as a function of time.
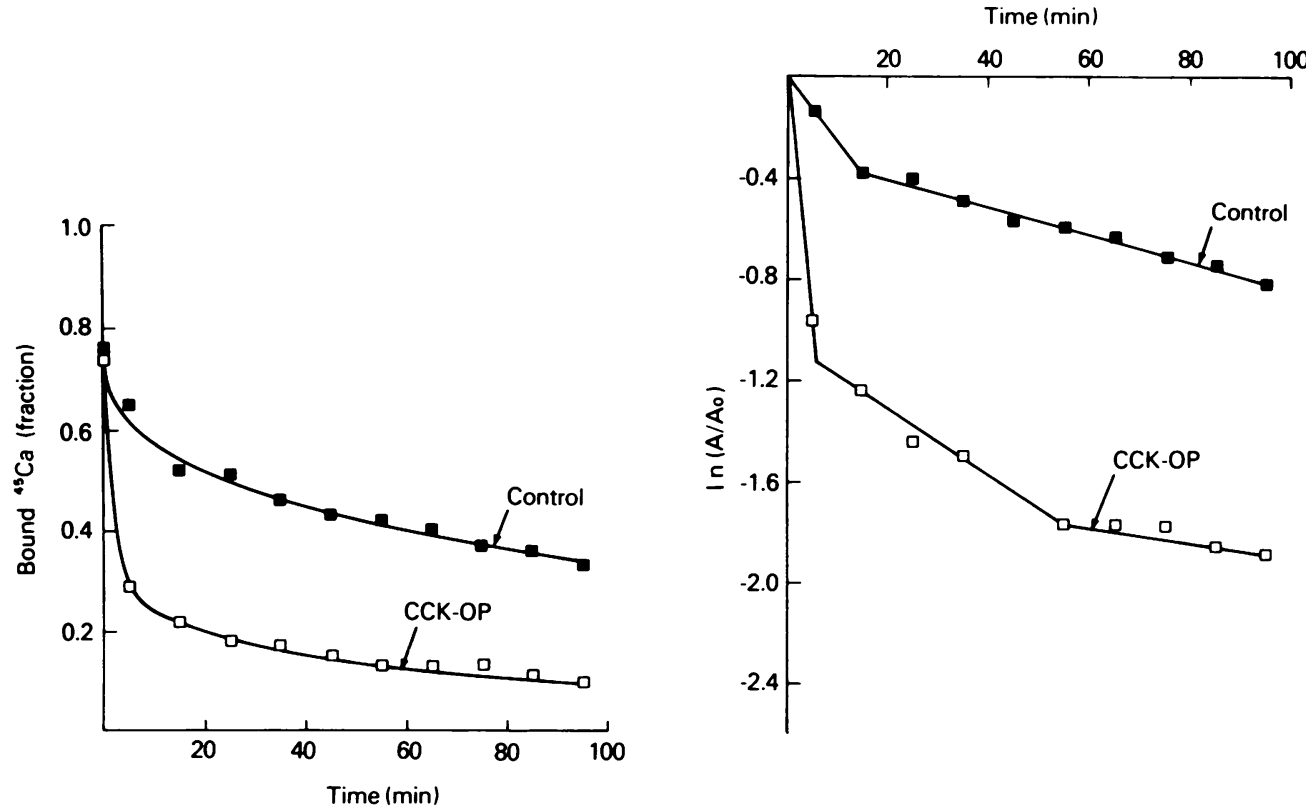

FIGURE 6 Effect of CCK-OP on the loss of membrane-bound ${ }^{45} \mathrm{Ca}$ from dispersed guinea pig pancreatic acinar cells. Dispersed cells were preincubated in Krebs-Ringer bicarbonate (pH 7.4) containing $1 \%$ (wt/vol) albumin and $0.5 \mathrm{mM}{ }^{45} \mathrm{Ca}$ for $60 \mathrm{~min}$ at $37^{\circ} \mathrm{C}$. $5 \mathrm{mM}$ EDTA with or without $1 \mu \mathrm{M}$ CCK-OP was added and membrane-bound ${ }^{45} \mathrm{Ca}$ was determined at the times indicated during a 95-min incubation at $37^{\circ} \mathrm{C}$ (left panel). Each point was determined in triplicate and represents the mean of five experiments. In the right panel, the natural logarithm of the fraction of the amount of membrane-bound ${ }^{45} \mathrm{Ca}$ originally present is plotted as a function of time. 


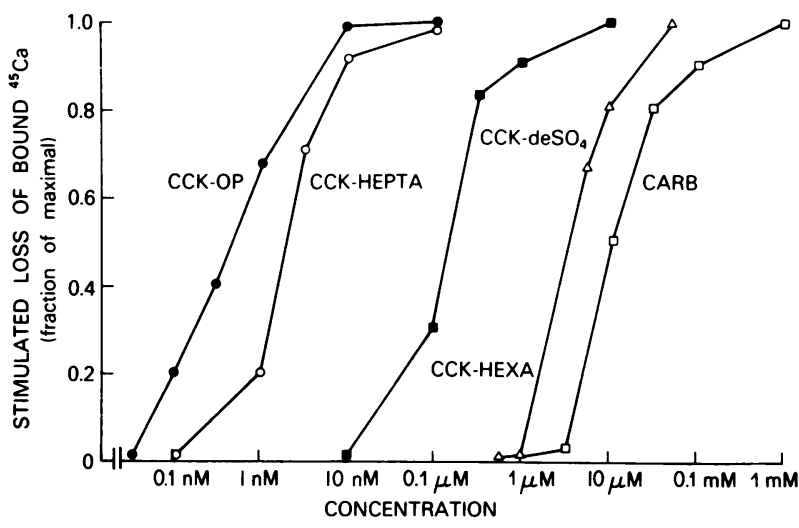

Figure 7 Stimulation of loss of membrane-bound ${ }^{45} \mathrm{Ca}$ from dispersed guinea pig pancreatic acinar cells by carbamylcholine and by synthetic fragments and analogs of porcine cholecystokinin. Dispersed cells were preincubated in KrebsRinger bicarbonate (pH 7.4) containing $1 \%$ (wt/vol) and 0.5 $\mathrm{mM}{ }^{45} \mathrm{Ca}$ for $60 \mathrm{~min}$ at $37^{\circ} \mathrm{C}$. Stimulation of loss of membranebound ${ }^{45} \mathrm{Ca}$ was determined during a 5 -min incubation at $37^{\circ} \mathrm{C}$ with $5 \mathrm{mM}$ EDTA plus the indicated agents. Values are expressed as the fraction of the stimulation produced by $1 \mu \mathrm{M}$ CCK-OP (i.e. fraction of maximal stimulation). Agents tested were carbamylcholine (open squares) and $\mathrm{COOH}$ terminal octapeptide (closed circles), heptapeptide (open circles), desulfated ocatpeptide (closed squares), and hexapeptide (open triangles) of cholecystokinin. Each point was determined in triplicate and is the mean of six separate experiments.

brane-bound ${ }^{45} \mathrm{Ca}$ from pancreatic acinar cells, while the COOH-terminal hexapeptide (CCK-HEXA) was 50,000 times less potent than CCK-OP (Fig. 7). Removing the sulfate from the tyrosine moiety of CCK-OP $\left(\mathrm{CCK}\right.$-deSO $\left.{ }_{4}\right)$ produced a 1,000 -fold reduction in the potency with which the peptide incerased release of membrane-bound ${ }^{45} \mathrm{Ca}$. Sufficiently high concentrations of CCK-HEPTA, CCK-HEXA, or CCK$\mathrm{deSO}_{4}$ increased the loss of membrane-bound ${ }^{45} \mathrm{Ca}$ as much as a maximal concentration of CCK-OP. The release of membrane-bound ${ }^{45} \mathrm{Ca}$ produced by maximal concentrations of any two of these peptides was the same as that produced by a maximal concentration of either alone (results not shown). Stimulation of release of membrane-bound ${ }^{45} \mathrm{Ca}$ was also a saturable function of the concentration of carbamylcholine. Significant effects of the cholinergic agent could be detected at $10 \mu \mathrm{M}$, and stimulation was maximal at $1 \mathrm{mM}$.

Previously (5) we found that the stimulation of ${ }^{45} \mathrm{Ca}$ outflux from pancreatic acinar cells by maximal concentrations of CCK-OP plus carbamylcholine was the same as that produced by a maximal concentration of either agent alone. Furthermore, atropine did not alter basal ${ }^{45} \mathrm{Ca}$ outflux or stimulation of outflux by CCK-OP but abolished the effect of carbamylcholine. In the present study we found similar effects in terms of the ability of various agents to stimulate release of membrane-bound ${ }^{45} \mathrm{Ca}$ from cells preloaded with the tracer and then incubated for $5 \mathrm{~min}$ with 5 mM EDTA (Table III). That is, CCK-OP and carbamylcholine but not atropine increased the loss of membrane-bound ${ }^{45} \mathrm{Ca}$. The increase produced by maximal concentrations of CCK-OP plus carbamylcholine was the same as that produced by a maximal concentration of either agent alone. Atropine did not alter the effect of CCK-OP but abolished the stimulation produced by carbamylcholine.

In cells preloaded with $0.5 \mathrm{mM}{ }^{45} \mathrm{Ca}$ and then incubated with $1 \mathrm{mM}$ carbamylcholine, membranebound ${ }^{45} \mathrm{Ca}$ decreased by $40 \%$ after $5 \mathrm{~min}$ and remained constant for the duration of the 25-min incubation (Fig. 8). When $1 \mathrm{mM}$ atropine (enough to abolish the effect of carbamylcholine) was added $5 \mathrm{~min}$ after carbamylcholine, membrane-bound ${ }^{45} \mathrm{Ca}$ increased toward control values during the subsequent $20 \mathrm{~min}$ of incubation.

In cells preincubated with ${ }^{45} \mathrm{Ca}$ and then incubated with CCK-OP, membrane-bound ${ }^{45} \mathrm{Ca}$ decreased by $40 \%$ within 5-10 min and then remained constant for the duration of the incubation (Fig. 9). In cells incubated for $25 \mathrm{~min}$ with CCK-OP, adding $5 \mathrm{mM}$ EDTA produced a further decrease in membranebound ${ }^{45} \mathrm{Ca}$ and this decrease was more rapid than in cells incubated with EDTA alone (Fig. 9). In cells incubated for $25 \mathrm{~min}$ with EDTA, adding CCK-OP significantly accelerated the rate of loss of membrane-bound ${ }^{45} \mathrm{Ca}$ (Fig. 9). Furthermore, the rate of

\section{TABLE III}

Effect of CCK-OP and Carbamylcholine on Loss of Membrane-bound ${ }^{45} \mathrm{Ca}$ from Dispersed Guinea Pig Pancreatic Acinar Cells

\begin{tabular}{lc}
\hline \multicolumn{1}{c}{ Additions } & Membrane-bound ${ }^{45} \mathrm{Ca}$ \\
\hline & $\%$ of control \\
None & $100 \pm 8$ \\
Atropine $(1 \mathrm{mM})$ & $100 \pm 2$ \\
Carbamylcholine $(1 \mathrm{mM})$ & $50 \pm 4^{*}$ \\
CCK-OP $(0.1 \mu \mathrm{M})$ & $44 \pm 3^{*}$ \\
CCK-OP plus carbamylcholine & $45 \pm 4^{*}$ \\
CCK-OP plus atropine & $47 \pm 2^{*}$ \\
Carbamylcholine plus atropine & $100 \pm 6$ \\
\hline
\end{tabular}

Dispersed pancreatic acinar cells were preincubated in standard buffer containing $0.5 \mathrm{mM}{ }^{45} \mathrm{Ca}$ for $60 \mathrm{~min}$ at $37^{\circ} \mathrm{C}$ and then incubated for $5 \mathrm{~min}$ with $5 \mathrm{mM}$ EDTA plus the agents indicated. Membrane-bound ${ }^{45} \mathrm{Ca}$ is given as the percent of that determined in acinar cells incubated with EDTA alone. Results are means from four separate experiments \pm 1 SD.

* Significantly less $(P<0.01)$ than membrane-bound ${ }^{45} \mathrm{Ca}$ in cells incubated with 5 mM EDTA alone by Student's $t$ test. 


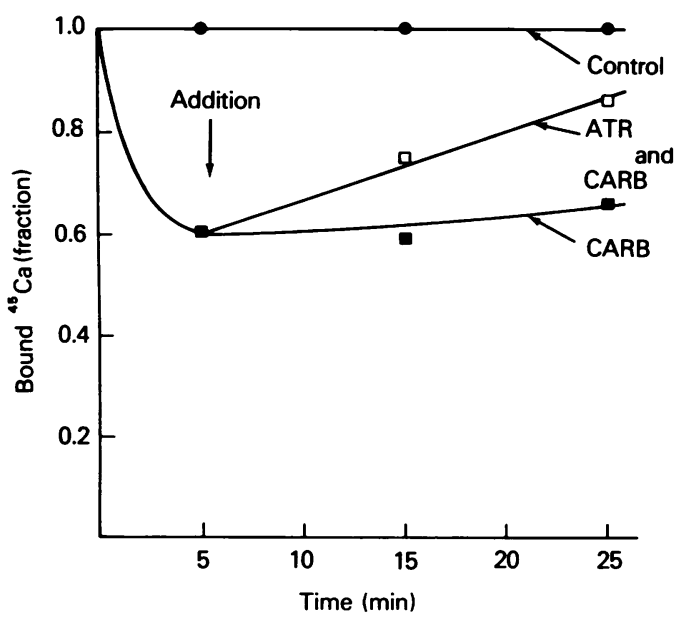

FIGURE 8 Ability of atropine (ATR) to reverse the effect of carbamylcholine (CARB) on membrane-bound ${ }^{45} \mathrm{Ca}$ in dispersed guinea pig pancreatic acinar cells. Dispersed cells were preincubated in Krebs-Ringer bicarbonate ( $\mathrm{pH} \mathrm{7.4)}$ containing $1 \%$ (wt/vol) albumin and $0.5 \mathrm{mM}{ }^{45} \mathrm{Ca}$ for 60 $\mathrm{min}$ at $37^{\circ} \mathrm{C}$. After the preincubation, $1 \mathrm{mM}$ carbamylcholine was added to two portions of cells and then 5 min later (arrow) $1 \mathrm{mM}$ atropine was added to one of these. Membranebound ${ }^{45} \mathrm{Ca}$ was determined at the times indicated and is expressed as the fraction of the amount present at the beginning of the incubation. Each point was determined in triplicate and is the mean of four separate experiments.

loss of membrane-bound ${ }^{45} \mathrm{Ca}$ after addition of CCK-OP to cells incubated for $25 \mathrm{~min}$ with EDTA was the same as that seen after addition of EDTA to acinar cells incubated for $25 \mathrm{~min}$ with CCK-OP (Fig. 9).

CCK-OP did not alter uptake of membrane-bound ${ }^{45} \mathrm{Ca}$ during the initial $30 \mathrm{~min}$ of incubation (Fig. 4), but in acinar cells preincubated with the tracer for $60 \mathrm{~min}$, the peptide produced a prompt $40 \%$ decrease in membrane-bound ${ }^{45} \mathrm{Ca}$ (Figs. 3, 9). To explore this apparent discrepancy, cells were preincubated with ${ }^{45} \mathrm{Ca}$ and at different times the decrease in membrane-bound ${ }^{45} \mathrm{Ca}$ was determined during a 5-min incubation with CCK-OP (Fig. 10). After $5 \mathrm{~min}$ of preincubation, CCK-OP decreased membrane-bound ${ }^{45} \mathrm{Ca}$ by $20 \%$. As the time of preincubation increased, the percent of bound ${ }^{45} \mathrm{Ca}$ released by CCK-OP increased, so that by $35 \mathrm{~min} 40 \%$ of membrane-bound ${ }^{45} \mathrm{Ca}$ was released by CCK-OP during a 5 -min incubation. Preincubating cells beyond $35 \mathrm{~min}$ did not increase the percent of membrane-bound ${ }^{45} \mathrm{Ca}$ released by CCK-OP.

\section{DISCUSSION}

In the present study we explored the effect of cholecystokinin and cholinergic agents on fluxes of exchangeable calcium in dispersed acinar cells from guinea pig pancreas. In agreement with the results of Kondo and Schulz (21), we found that only $4 \%$ of the calcium

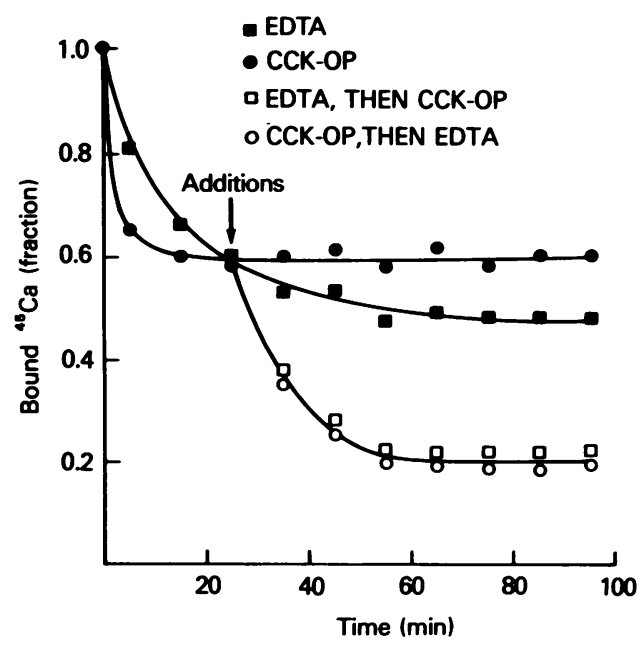

FIGURE 9 Effect of sequential additions of CCK-OP and EDTA on membrane-bound ${ }^{45} \mathrm{Ca}$ in dispersed guinea pig pancreatic acinar cells. Dispersed cells were preincubated in Krebs-Ringer bicarbonate ( $\mathrm{pH} 7.4$ ) containign $1 \%$ (wt/vol) albumin and $0.5 \mathrm{mM}{ }^{45} \mathrm{Ca}$ for $60 \mathrm{~min}$ at $37^{\circ} \mathrm{C}$. EDTA $(5 \mathrm{mM})$ was added to two portions of cells and then 25 min later (arrow) $1 \mu \mathrm{M}$, CCK-OP was added to one of these. CCK-OP $(1 \mu \mathrm{M})$ was added to two other portions of cells and then $25 \mathrm{~min}$ later (arrow) EDTA $(5 \mathrm{mM})$ was added to one of these. Membrane-bound ${ }^{45} \mathrm{Ca}$ was determined at the times indicated and is expressed as the fraction of the amount present at the beginning of the incubation. Each point was determined in triplicate and is the mean of three separate experiments.

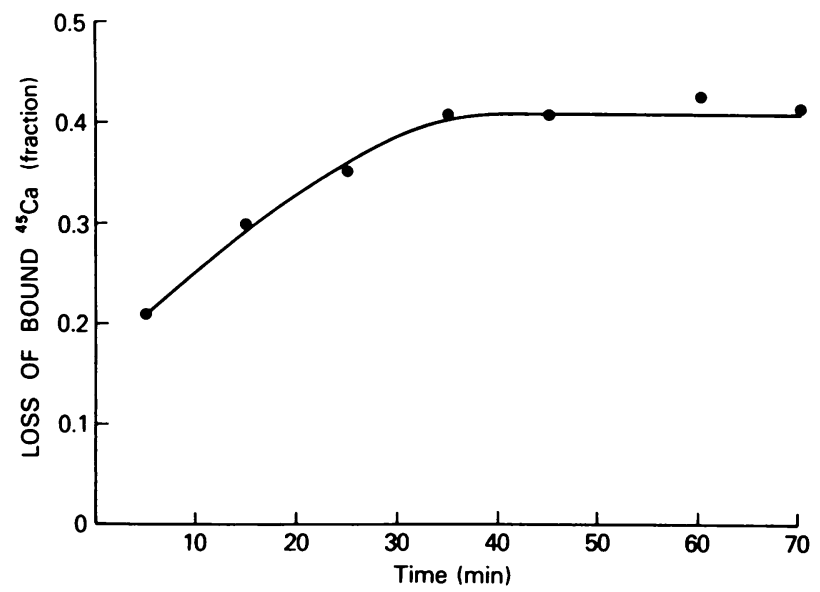

FIGURE 10 Effect of preincubation time on the ability of CCK-OP to cause loss of membrane-bound ${ }^{45} \mathrm{Ca}$ from dispersed guinea pig pancreatic acinar cells. Dispersed cells were preincubated in Krebs-Ringer bicarbonate ( $\mathrm{pH}$ 7.4) containing $1 \%$ (wt/vol) albumin and $0.5 \mathrm{mM}$ calcium. ${ }^{45} \mathrm{Ca}$ (approximately $10^{7} \mathrm{cpm} / \mathrm{ml}$ of cell suspension) was added and at the times indicated the loss of membrane-bound ${ }^{45} \mathrm{Ca}$ was determined during a 5-min incubation with $1 \mu \mathrm{M}$ CCK-OP. Values are expressed as the fraction of membranebound ${ }^{45} \mathrm{Ca}$ lost during the incubation with CCK-OP. Each point was determined in triplicate and is the mean of three separate experiments. 
present in acinar cells is exchangeable. These values with dispersed acinar cells are significantly lower than those obtained by others $(1,3,4,22)$ measuring exchangeable calcium in pancreas in vitro and may be attributable to changes during the dissociation procedure. As observed by others $(1,4)$, neither cholecystokinin nor carbamylcholine altered total cellular calcium. Each agent, however, caused a prompt decrease in exchangeable cellular ${ }^{45} \mathrm{Ca}$ attributable to a loss of membrane-bound ${ }^{45} \mathrm{Ca}$.

We have determined membrane-bound ${ }^{45} \mathrm{Ca}$ by incubating acinar cells with tracer, disrupting the cells with iced $10 \mathrm{mM}$ EDTA, and measuring the radioactivity retained on a Millipore filter. In control cells approximately $70 \%$ of total cellular ${ }^{45} \mathrm{Ca}$ was membrane-bound. In identical studies with ${ }^{42} \mathrm{~K}$ or the nonmetabolized amino acid $\left[{ }^{14} \mathrm{C}\right] \mathrm{AIB}$, virtually no cellular radioactivity was retained on the filter. These results indicate that what we measure as membrane-bound ${ }^{45} \mathrm{Ca}$ is not due to nonselective association of ${ }^{45} \mathrm{Ca}$ with cellular membranes or organelles and also exclude ${ }^{45} \mathrm{Ca}$ being retained on the filter in undisrupted cells.

It seemed possible that the ${ }^{45} \mathrm{Ca}$ retained on the filter might not represent radioactivity bound to membranes but instead ${ }^{45} \mathrm{Ca}$ sequestered (in a "free" form) in intact cellular organelles. We found that treating acinar cells with iced $10 \mathrm{mM}$ EDTA disrupted nuclei and zymogen granules; therefore, the ${ }^{45} \mathrm{Ca}$ retained on the filter cannot represent radioactivity sequestered within these organelles. The hypotonic EDTA solution did not appear to disrupt the inner mitochondrial membrane which is capable of transporting calcium and causing considerable accumulation of the cation in the mitochondrial matrix (23-27). Although the free calcium concentration in the mitochondrial matrix has not been determined, most of this calcium is thought to be bound (26).

We should point out that we are not certain that we have detected all of the cellular ${ }^{45} \mathrm{Ca}$ that is, in fact, membrane-bound. It is possible that some of the bound ${ }^{45} \mathrm{Ca}$ dissociated during the $20 \mathrm{~s}$ required for lysing, filtration, and washing, or that our lysing procedure produced membrane "fragments" to which ${ }^{45} \mathrm{Ca}$ was bound but which were sufficiently small that they passed through the Millipore filter. On the other hand, during lysing and filtration some of the free cellular ${ }^{45} \mathrm{Ca}$ (either in the cell cytoplasm or in cellular organelles) may associate with membranes and be measured as bound ${ }^{45} \mathrm{Ca}(28)$. Even with these limitations, however, the loss of ${ }^{45} \mathrm{Ca}$ from pancreatic acinar cells caused by cholecystokinin or cholinergic agents can be accounted for by a decrease in what we measure as membrane-bound ${ }^{45} \mathrm{Ca}$.

We should also point out that we do not know the cellular structures to which ${ }^{45} \mathrm{Ca}$ is bound. Clemente and Meldolesi (28) have found that in homogenates of intact guinea pig pancreas, the distribution of tissue calcium is: zymogen granules, $35 \%$; zymogen granule membranes, $6 \%$; plasma membranes, $5 \%$; mitochondria, $6 \%$; microsomes, $19 \%$. In a subsequent study (22), these same investigators measured radioactivity recovered in subcellular fractions of pancreatic lobules incubated with ${ }^{45} \mathrm{Ca}$. Of the total tissue ${ }^{45} \mathrm{Ca}, 17 \%$ was recovered with mitochondria, and caerulein reduced mitochondrial ${ }^{45} \mathrm{Ca}$ by approximately $40 \%$. (Caerulein did not alter recovery of ${ }^{55} \mathrm{Ca}$ in any of the other cellular fractions.) If a similar distribution of ${ }^{45} \mathrm{Ca}$ exists in our preparation, an effect of this magnitude (i.e. $7 \%$ decrease in total tissue ${ }^{45} \mathrm{Ca}$ ) would not be sufficient to account for our finding that CCK-OP or cholinergic agents cause a $40 \%$ decrease in cellular ${ }^{45} \mathrm{Ca}$.

Our results indicate that of the calcium present in pancreatic acinar cells only about $1 \%$ is free. That is, $4 \%$ of cellular calcium is exchangeable and of this onethird is free. We want to emphasize that what we have termed "free" cellular ${ }^{45} \mathrm{Ca}$ was not measured directly but was calculated as the difference between total cellular and membrane-bound ${ }^{45} \mathrm{Ca}$. That is, with the technique used for the present experiments, free cellular ${ }^{45} \mathrm{Ca}$ is defined as that portion of total cellular ${ }^{45} \mathrm{Ca}$ not detected as being membrane-bound. Since the value of free cellular ${ }^{45} \mathrm{Ca}$ is calculated as a difference, it will reflect errors in either of the determinations from which it is derived. For example, incomplete collection of membranes on the filter or loss of membrane-bound ${ }^{45} \mathrm{Ca}$ during lysis and filtration will result not only in underestimation of the fraction of total cellular ${ }^{45} \mathrm{Ca}$ that is membrane-bound but also in overestimation of the fraction that is free. ${ }^{4}$

What we have calculated as "free cellular ${ }^{45} \mathrm{Ca}$ " should not be interpreted to mean "cytoplasmic ${ }^{45} \mathrm{Ca}$ ", since our technique does not distinguish between radioactivity free in the cytoplasm and free but localized to anatomically defined cellular compartments such as mitochondria, nuclei, or zymogen granules. What we have termed free cellular ${ }^{45} \mathrm{Ca}$ should also not be interpreted to mean "ionized ${ }^{45} \mathrm{Ca}$ " since our technique does not distinguish between ionized ${ }^{45} \mathrm{Ca}$ and free ${ }^{45} \mathrm{Ca}$ complexed to nucleotides, proteins, etc. (29-31). In the relatively few cell types studied, ionized calcium has been found to be on the order of $0.1 \%$ of the total cellular calcium (29-32). For example, in squid axon about $3 \%$ of total calcium

${ }^{4}$ The magnitude by which we may have overestimated the fraction of total free cellular ${ }^{45} \mathrm{Ca}$ can be illustrated by assuming that in intact acinar cells $99.5 \%$ of cellular ${ }^{45} \mathrm{Ca}$ is actually membrane-bound and only $0.5 \%$ is free. Our technique, which indicates that $70 \%$ of the cellular ${ }^{45} \mathrm{Ca}$ is bound, would underestimate membrane-bound ${ }^{45} \mathrm{Ca}$ by $30 \%$ but would overestimate free cellular ${ }^{45} \mathrm{Ca}$ by $6,000 \%$ 
is present in axoplasm in an un-ionized form presumably complexed to nucleotides and proteins, while approximately $0.01 \%$ of the cellular calcium is ionized in the cytoplasm (29).

One hypothesis proposed to explain the role of calcium in the action of cholecystokinin and cholinergic agents on pancreatic exocrine function is similar to "stimulus-secretion coupling" originally proposed to account for release of catecholamines from adrenal medulla (33). This interpretation proposes that the secretagogue initiates influx of calcium, which then by some unknown sequence of events causes enzyme secretion. This hypothesis is based primarily on the observation that stimulation of pancreatic enzyme secretion by cholecystokinin or cholinergic agents is inhibited when calcium is removed from the incubation medium (4, 34-39). Furthermore, the divalent cation ionophore A23187 increases cellular calcium content and stimulates enzyme secretion in pancreatic fragments, and ionophore-stimulated secretion is abolished in a calcium-free medium (40-42). Finally, Heisler and Grondin (43) reported that carbamylcholine increased uptake of ${ }^{45} \mathrm{Ca}$ in fragments of rat pancreas, while Kondo and Schulz (21) found that cholecystokinin and carbamylcholine increased uptake of ${ }^{45} \mathrm{Ca}$ by dispersed acinar cells prepared from rat pancreas. The basis for the discrepancy between these observations and the findings by us $(5,6)$ and others (1-4) that CCK-OP and cholinergic agents either do not alter or slightly decrease cellular uptake of ${ }^{45} \mathrm{Ca}$ is presently unclear.

A number of observations are not consistent with the proposal that secretagogues stimulate pancreatic enzyme secretion by causing calcium influx. Bethanechol-stimulated pancreatic enzyme secretion can occur in a calcium-free medium (4). Cholecystokinin and cholinergic agents have been found not to alter calcium influx but to increase calcium outflux significantly in intact pancreas (1), pancreatic fragments $(2-4)$, and dispersed pancreatic acinar cells $(5,6)$. Furthermore, cholecystokinin and cholinergic agents increase cellular cyclic GMP in dispersed pancreatic acinar cells, and the magnitude of the increase is independent of the concentration of extracellular calcium (6). A23187 not only increases uptake of ${ }^{45} \mathrm{Ca}$ in pancreatic acinar cells but also stimulates ${ }^{45} \mathrm{Ca}$ outflux and increases cellular cyclic GMP (6). Ionophore stimulation of ${ }^{45} \mathrm{Ca}$ outflux as well as the increase in cellular cyclic GMP can occur in a calciumfree EGTA-containing medium (6). These findings indicate that one of the early steps in the action of cholecystokinin and cholinergic agents on pancreatic acinar cells is to cause release of exchangeable cellular calcium. On the basis of these findings, some investigators $(1,3,4,9)$ have proposed that secretagogues cause release of intracellular stored calcium and by so doing increase free cytoplasmic calcium. None of these studies, however, has included measurements of stored calcium or free cytoplasmic calcium.

Since we do not know the cellular structures to which ${ }^{45} \mathrm{Ca}$ is bound, we cannot state whether the loss of membrane-bound radioactivity caused by CCK-OP represents release of stored intracellular ${ }^{45} \mathrm{Ca}$, as has been suggested by others $(1,3,4,9)$. It is possible, for example, that CCK-OP and cholinergic agents cause release of ${ }^{45} \mathrm{Ca}$ bound to the plasma membrane of the pancreatic acinar cell. In cells preloaded with the tracer, CCK-OP did increase free cellular ${ }^{45} \mathrm{Ca}$; however, this increase could not be detected until $30 \mathrm{~min}$ after the peptide was added. Since in acinar cells, CCK-OP causes release of membrane-bound ${ }^{45} \mathrm{Ca}$, an increase in cellular cyclic G.MP and stimulation of enzyme secretion $(5,6)$ within minutes (during which time free cellular ${ }^{45} \mathrm{Ca}$ does not change), this effect of CCK-OP on free cellular ${ }^{45} \mathrm{CA}$ cannot account for the increase in cellular cyclic nucleotide or enzyme secretion and is probably secondary to an effect of the peptide on some other aspect of cellular ${ }^{45} \mathrm{Ca}$ transport.

After CCK-OP is added to acinar cells preloaded with ${ }^{45} \mathrm{Ca}$, total cellular radioactivity decreases by $40 \%$ after $5 \mathrm{~min}$ and then steadily increases to control values by $60 \mathrm{~min}$. Previously (5), we found that after total cellular ${ }^{45} \mathrm{Ca}$ had returned to control values, a second addition of CCK-OP did not alter total cellular ${ }^{45} \mathrm{Ca}$, and concluded that calcium outflux in pancreatic acinar cells becomes refractory to stimulation by CCK-OP. The present results indicate that this conclusion was incorrect, and that what we previously termed "refractoriness" results from a persistent effect of CCK-OP coupled with a redistribution of cellular ${ }^{45} \mathrm{Ca}$. That is, after adding CCK-OP to acinar cells preloaded with ${ }^{45} \mathrm{Ca}$, membrane-bound radioactivity decreased rapidly within the first 5-10 $\mathrm{min}$ and remained constant for the duration of the incubation. Free ${ }^{45} \mathrm{Ca}$ did not change during the first 30 min after the peptide was added but then steadily increased so that after $60 \mathrm{~min}$ of incubation, free cellular ${ }^{45} \mathrm{Ca}$ was approximately three times that in control cells. Thus, after CCK-OP (or carbamylcholine) was added, the initial decrease in total cellular ${ }^{45} \mathrm{Ca}$ is attributable to a decrease in membrane-bound ${ }^{45} \mathrm{Ca}$. The subseuqent return of total cellular ${ }^{45} \mathrm{Ca}$ to control values reflects accumulation of free ${ }^{45} \mathrm{Ca}$.

The good agreement between the present experiments and identical studies of release of total cellular ${ }^{45} \mathrm{Ca}$ reported previously (5) is additional evidence indicating that the initial loss of total cellular ${ }^{45} \mathrm{Ca}$ produced by CCK-OP or carbamylcholine reflects the action of these agents on membranebound ${ }^{45} \mathrm{Ca}$. The dose-response curves for stimulation. of release of membrane-bound ${ }^{45} \mathrm{Ca}$ by $\mathrm{COOH}$ - 
terminal octapeptide, hepapeptide, hexapeptide, and desulfated octapeptide of cholecystokinin, as well as by carbamylcholine (Fig. 7) are the same as those for increasing outflux to total cellular ${ }^{45} \mathrm{Ca}$ by these same agents $(5,6)$. Atropine, which alone does not alter release of membrane-bound ${ }^{45} \mathrm{Ca}$, abolished the loss of membrane-bound ${ }^{45} \mathrm{Ca}$ produced by carbamylcholine but not that produced by CCK-OP. Similar effects have been reported with outflux of total cellular ${ }^{45} \mathrm{Ca}$ (5). Atropine was also able to reverse the decrease in membrane-bound ${ }^{45} \mathrm{Ca}$ produced by carbamylcholine, indicating that carbamylcholine (and presumably, CCK-OP as well) does not produce an irreversible loss of membrane-bound ${ }^{45} \mathrm{Ca}$.

In acinar cells preloaded with ${ }^{45} \mathrm{Ca}$ and then incubated with EDTA the loss of membrane-bound radioactivity could be described by the sum of two exponentials. These results are compatible with there being two distinct compartments: a relatively small compartment $\left(30 \%\right.$ of the total cellular $\left.{ }^{45} \mathrm{Ca}\right)$ having a high outflux coefficient and a relatively large compartment $\left(70 \%\right.$ of total cellular $\left.{ }^{45} \mathrm{Ca}\right)$ having a low outflux coefficient. The loss of bound ${ }^{45} \mathrm{Ca}$ during incubation with EDTA plus CCK-OP required three exponentials to fit the data. These results indicate that in pancreatic acinar cells, membrane-bound exchangeable calcium exists in several functionally distinct compartments, each of whose kinetic characteristics is altered by CCK-OP. From the present studies, however, we cannot specify which, if any, of these alterations represent the primary effect of the peptide.

To explore further the relation between the ${ }^{45} \mathrm{Ca}$ lost when preloaded cells were incubated with EDTA and that lost during incubation with CCK-OP, one of these two agents was added $25 \mathrm{~min}$ after the other. The loss of membrane-bound ${ }^{45} \mathrm{Ca}$ with CCK-OP plus EDTA was the same in cells previously incubated for 25 min with EDTA as in cells previously incubated for $25 \mathrm{~min}$ with CCK-OP. These results indicate that after CCK-OP was added, the compartment that loses membrane-bound ${ }^{45} \mathrm{Ca}$ rapidly was not affected by EDTA and the membrane-bound ${ }^{45} \mathrm{Ca}$ lost with CCK-OP was from compartments other than that which decreases rapidly with EDTA.

The time-course of the effect of CCK-OP on uptake of membrane-bound ${ }^{45} \mathrm{Ca}$ differed from its effect in cells preloaded with the tracer. After CCK-OP was added to preloaded cells, membrane-bound ${ }^{45} \mathrm{Ca}$ decreased and reached a constant minimum value by $5 \mathrm{~min}$, but in the uptake studies membrane-bound ${ }^{45} \mathrm{Ca}$ did not decrease until after $30 \mathrm{~min}$ of incubation. We also found that the fraction of membrane-bound ${ }^{45} \mathrm{Ca}$ which could be released by CCK-OP increased progressively during incubation and did not become maximal until after $30 \mathrm{~min}$. These results suggest that accumulation of ${ }^{45} \mathrm{Ca}$ in the CCK-OP sensitive compartment(s) is a relatively slow process and that at least $30 \mathrm{~min}$ is required before enough ${ }^{45} \mathrm{Ca}$ is released by CCK-OP to produce a detectable decrease in membrane-bound ${ }^{45} \mathrm{Ca}$.

\section{REFERENCES}

1. Case, R. M., and T. Clausen. 1973. The relationship between calcium exchange and enzyme secretion in the isolated rat pancreas. J. Physiol. (Lond.) 235: 75-102.

2. Matthews, E. K., O. H. Petersen, and J. A. Williams. 1973. Pancreatic acinar cells: acetylcholine-induced membrane depolarization, calcium efflux and amylase release. J. Physiol. (Lond.). 234: 689-701.

3. Chandler, D. E., and J. A. Williams. 1974. Pancreatic acinar cells: Effects of lanthanum ions on amylase release and calcium ion fluxes. J. Physiol. (Lond.). 243: 831-846.

4. Williams, J. A., and D. Chandler. 1975. $\mathrm{Ca}^{++}$and pancreatic amylase release. Am. J. Physiol. 228: 17291732.

5. Gardner, J. D., T. P. Conlon, H. L. Klaeveman, T. D. Adams, and M. A. Ondetti. 1975. Action of cholecystokinin and cholinergic agents on calcium transport in isolated pancreatic acinar cells. J. Clin. Invest. 56: 366375.

6. Christophe, J. P., E. K. Frandsen, T. P. Conlon, G. Krishna, and J. D. Gardner. 1976. Action of cholecystokinin, cholinergic agents and A-23187 on accumulation of cyclic GMP in dispersed guinea pig pancreatic acinar cells. J. Biol. Chem. 251: 4640-4645.

7. Gardner, J. D., T. P. Conlon, and T. D. Adams. 1976. Cyclic AMP in pancreatic acinar cells: effects of gastrointestinal hormones. Gastroenterology. 70: 2935 .

8. Robberecht, P., T. P. Conlon, and J. D. Gardner. 1976. Interaction of porcine vasoactive intestinal peptide with dispersed acinar cells from the guinea pig: structural requirements for effects of VIP and secretin on cellular cyclic AMP. J. Biol. Chem. 251: 4635-4639.

9. Williams, J. A. 1974. Intracellular control mechanisms regulating secretion by exocrine and endocrine glands. In Secretory Mechanisms of Exocrine Glands. N. A. Thorn and O. H. Peterson, editors. Munksgaard, A/S, Copenhagen. 389-407.

10. Amsterdam, A., and J. D. Jamieson. 1972. Structural and functional characterization of isolated pancreatic exocrine cells. Proc. Natl. Acad. Sci. U. S. A. 69: 30283032.

11. Amsterdam, A., and J. D. Jamieson. 1974. Studies on dispersed pancreatic exocrine cells. I. Dissociation technique and morphologic characteristics of separated cells. J. Cell Biol. 63: 1037-1056.

12. Amsterdam, A., and J. D. Jamieson. 1974. Studies on dispersed pancreatic exocrine cells. II. Functional characteristics of separated cells. J. Cell Biol. 63: 1057-1073.

13. Eagle, H. 1959. Amino acid metabolism in mammalian cell cultures. Science (Wash. D. C.). 130: 432-437.

14. Meldolesi, J., J. D. Jamieson, and G. Palade. 1971. Composition of cellular membranes in the pancreas of the guinea pig. I. Isolation of membrane fractions. J. Cell Biol. 49: 109-129.

15. Kissane, J. M., and E. Robins. 1958. The fluorometric measurement of deoxyribonucleic acid in animal tissue 
with special reference to the central nervous system. J. Biol. Chem. 43: 184-188.

16. Ceska, M., B. Brown, and K. Birath. 1969. Ranges of $\alpha$-amylase activities in human serum and urine and correlations with some other $\alpha$-amylase methods. Clin. Chim. Acta 26: 445-453.

17. Ceska, M., K. Birath, and B. Brown. 1969. A new and rapid method for the clinical determination of $\alpha$-amylase in human serum and urine. Optimal conditions. Clin. Chim. Acta. 26: 437-444.

18. Pennington, J. 1961. Biochemistry of dystrophic muscle. Mitochondrial succinate-tetrazolium reductase and adenosine triphosphate. Biochem. J. 80: 649-654.

19. Ontko, J. A., and N. Dashti. 1976. Enzymes of mitochondria. Part I. Properties. In Cell Biology, P. L. Altman and D. D. Katz, editors. Federation of American Societies for Experimental Biology, Bethesda, Md. 161-179.

20. Steck, T. 1972. Membrane isolation. In Membrane Molecular Biology. C. F. Fox and A. Keith, editors. Sinauer Associates Inc., Stamford, Conn. 76-114.

21. Kondo, S., and I. Schulz. 1976. Calcium uptake in isolated pancreas cells induced by secretagogues. Biochim. Biophys. Acta. 419: 76-92.

22. Clemente, F., and J. Meldolesi. 1975. Calcium and pancreatic secretion. Dynamics of subcellular calcium pools in resting and stimulated acinar cells. $\mathrm{Br}$. J. Pharmacol. 55: 369-379.

23. Chance, B. 1965. The energy linked reaction of calcium with mitochondria. J. Biol. Chem. 240: 2729-2738.

24. Carafoli, E. 1967. In vivo effect of uncoupling agents on the incorporation of calcium and strontium into mitochondria and other subcellular fractions of rat liver. J. Gen. Physiol. 50: 1849-1864.

25. Mela, L., and B. Chance, 1968. Spectrophotometric measurements of the kinetics of $\mathrm{Ca}^{2+}$ and $\mathrm{Mn}^{2+}$ accumulation in mitochondria. Biochemistry 7: 4059-4072.

26. Lehninger, A. L. 1970. Mitochondria and calcium ion transport. Biochem. J. 119: 129-138.

27. Cittadini, A., A. Scarpa, and B. Chance. 1973. Calcium transport in intact Ehrlich ascites tumor cells. Biochem. Biophys. Acta. 291: 246-259.

28. Clemente, F., and J. Meldolesi. 1975. Calcium and pancreatic secretion. I. Subcellular distribution of calcium and magnesium in the exocrine pancreas of the guinea pig. J. Cell. Biol. 65: 88-102.

29. Baker, P. F., A. L. Hodgkin, and E. B. Ridgway. 1971. Depolarization and calcium entry in squid giant axons. J. Physiol. (Lond.). 218: 709-755.

30. Baker, P. F. 1972. Transport and metabolism of calcium ions in nerve. Prog. Biophys. Mol. Biol. 24: 177-224.
31. Brinley, F. J., Jr. 1973. Calcium and magnesium transport in single cells. Fed. Proc. 32: 1735-1739.

32. Schatzmann, H. J., and F. F. Vincenzi, 1969. Calcium movements across the membrane of human red cells. J. Physiol. (Lond.). 201: 369-395.

33. Douglas, W. W. 1968. Stimulus-secretion coupling: the concept and clues from chromaffin and other cells. Br. J. Pharmacol. 34: 451-474.

34. Hokin, L. E. 1966. Effects of calcium omission on acetylcholine stimulated amylase secretion and phospholipid synthesis in pigeon pancreas slices. Biochim. Biophys. Acta. 115: 219-221.

35. Robberecht, P., and J. Christophe. 1971. Secretion of hydrolases by perfused fragments of rat pancreas: effects of calcium. Am. J. Physiol. 220: 911-917.

36. Benz, L., B. Eckstein, E. K. Matthews, and J. A. Williams. 1972. Control of pancreatic amylase release in vitro: effects of ions, cyclic AMP and colchicine. $\mathrm{Br} . \mathrm{J}$. Pharmacol. 46: 66-77.

37. Heisler, S., D. Fast, and A. Tenenhouse. 1972. Role of $\mathrm{Ca}^{+}$and cyclic AMP in protein secretion from rat exocrine pancreas. Biochim. Biophys. Acta. 279: 561572.

38. Kanno, T. 1972. Calcium-dependent amylase release and electrophysiological measurements in cells of the pancreas. J. Physiol. (Lond.). 226: 353-371.

39. Argent, B. E., R. M. Case, and T. Scratcherd. 1973. Amylase secretion by the perfused cat pancreas in relation to the secretion of calcium and other electrolytes and as influenced by the external ionic environment. J. Physiol. (Lond.). 230: 575-593.

40. Williams, J. A., and M. Lee. 1974. Pancreatic acinar cells: use of $\mathrm{Ca}^{++}$ionophore to separate enzyme release from the earlier steps in stimulus-secretion coupling. Biochem. Biophys. Res. Commun. 60: 542-548.

41. Eimerl, S., N. Savion, O. Heichal, and Z. Selinger. 1974. Induction of enzyme secretion in rat pancreatic slices using the ionophore A-23187 and calcium. An experimental bypass of the hormone receptor pathway. J. Biol. Chem. 249: 3991-3993.

42. Selinger, Z., S. Eimerl, N. Savion, and M. Schramm. 1974. A $\mathrm{Ca}^{++}$ionophore A23187 stimulating hormone and neurotransmitter action in the rat parotid and pancreas glands. In Secretory Mechanisms of Exocrine Glands. N. A. Thorn and O. H. Petersen, editors. Academic Press, Inc., New York, 68-87.

43. Heisler, S., and G. Grondin. 1973. Effect of lanthanum on ${ }^{45} \mathrm{Ca}$ flux and secretin of protein from rat pancreas. Life Sci. 13: 783-794. 